Article

\title{
Socio-Economic Participation of Somali Refugees in the Netherlands, Transnational Networks and Boundary Spanning
}

\author{
Ilse van Liempt* and Gery Nijenhuis \\ Department of Human Geography and Spatial Planning, Utrecht University, 3584 CB, Utrecht, The Netherlands; E-Mails: \\ i.c.vanliempt@uu.nl (I.V.L.), g.nijenhuis@uu.nl (G.N.) \\ * Corresponding author
}

Submitted: 30 August 2019 | Accepted: 23 December 2019 | Published: 25 March 2020

\begin{abstract}
In this article we analyse the socio-economic participation of Somali refugees in the Netherlands. Unemployment is higher among Somalis than any other refugee or immigrant group in the Netherlands and they face many obstacles when it comes to social and economic participation. At the same time, they are known for having a strong transnational orientation. We were interested to learn whether and, if so, how Somalis use their transnational networks to overcome obstacles on the Dutch labour market and how boundaries around formal labour markets are negotiated in order to access employment and to participate. We did so by focusing on two strategies employed to participate, namely through Somali organizations in the Netherlands and elsewhere, and by Somalis moving to the UK. In doing so, we looked at Somalis' ability to span boundaries to create opportunities. The concept of transnational networks is helpful in understanding Somalis' daily realities, but conceptually it does not seem to fit entirely as these networks usually only refer to connections with the 'homeland.' We argue that Somalis' boundary-spanning activities move beyond national levels and involve various scales, sites, and settings. The data we refer to are derived from focus group discussions with 66 Somali people in Amsterdam and 20 interviews with experts who work with the Somali community in the Netherlands. These discussions and interviews were held in 2013-14. We also draw on 20 interviews with Somali organizations in the Netherlands about their transnational orientation, which were conducted between 2010 and 2013 in the context of another research project.
\end{abstract}

\section{Keywords}

boundary spanning; socio-economic participation; Somalis; transnational networks

Issue

This article is part of the issue "Boundary Spanning and Reconstitution: Migration, Community and Belonging" edited by Anya Ahmed (University of Salford, UK).

(C) 2020 by the authors; licensee Cogitatio (Lisbon, Portugal). This article is licensed under a Creative Commons Attribution 4.0 International License (CC BY).

\section{Introduction}

Many Somalis in the Netherlands find themselves in a vulnerable position on the Dutch labour market, which translates into the highest unemployment figures amongst immigrant and refugee groups in the Netherlands. More than $30 \%$ are unemployed compared to $15 \%$ of all non-Western immigrants (Andriessen, Gijsberts, Huijnk, \& Nicolaas, 2017). At the same time, Somalis are known for their strong transnational orientation (Horst, 2008; Ismail, 2011) and their entrepreneurial activities. In this article, we raise the question whether and, if so, how transnational networks are used to overcome obstacles on the Dutch labour market and how this impacts their socio-economic participation. We thus analyse Somalis' socio-economic participation through a transnational lens and move beyond national levels by taking various scales, sites, and settings into account. Networks can be formal or informal, and can have different qualities. In the literature, a distinction is often made between strong and weak ties (Granovetter, 1973). Strong ties are often based on connections through fam- 
ily and friends, as well as on a shared country of origin. Weak ties are much looser and can be ties between acquaintances or business relations. These weak ties are, however, crucial in exchanging information across different groups and binding together groups of strong ties (i.e., networks). Networks can be helpful in facilitating mobility (Massey et al., 1998). Migrant networks can serve different goals, as they can be used to share information about, for example, a migration destination or job opportunities. Upon arrival, many migrants fall back on their networks for housing, jobs, and all sorts of practical issues related to the country of destination. Through networks people also send money back to their relatives at home and elsewhere, and networks can help to facilitate onward migration (Danso, 2001; Dekker \& Engbersen, 2014; Poros, 2001; Ryan, Sales, Mary, \& Siara, 2008), just like they can facilitate initial migration. Networks thus can be used before, during, and after migration as well as in preparation for new trajectories.

The literature on migration and networks is in general rather positive, especially the literature that looks into the use of networks for integration purposes. Migrants using their own networks to find jobs is often perceived as an efficient way of gaining employment. A few authors, however, nuance this picture because labour market participation through social networks often results in migrants having lower pay and a more homogenous labour market position (i.e., as lower skilled workers). Migrants' own networks thus often result in less attractive jobs and working conditions (Kalter \& Kogan, 2014; McKay, 2009).

Another observation is that the literature on the role of networks in socio-economic integration is often limited to an analysis of networks at a local and national scale and does not take into account the transnational dimension. When the transnational perspective is taken into account, it is usually argued that transnationalism limits integration (Portes, Escobar, \& Arana, 2008; Snel, Engbersen, \& Leerkes, 2006). Since 2001, Western states have increasingly questioned the political loyalty of their immigrant residents (Waldinger \& Fitzgerald, 2004). In the Netherlands, for instance, the government opposes dual citizenship because it deems the resulting dual loyalties of migrants unacceptable and requires immigrants to have citizenship of only one country. Transnational activities (e.g., sending remittances) and a continuing identification with the sending country or the diaspora are often perceived as an impediment to the integration of immigrants into the host country. Taking into account Somalis' strong transnational orientation, for the purpose of this article we take a closer look at the role transnational networks play in their socio-economic participation. We do so by looking beyond the nation state and using the concept of boundary spanning, that is, the 'crossing, weaving and permeating' (Williams, 2002) of boundaries. These boundaries can take many forms: They can be national borders, but also organizational, sectoral, professional, linguistic, and cultural and political borders
(Jöns \& Freytag, 2015). Examples from the literature point to partnerships between universities and local communities as institutional boundary spanning (Weerts \& Sandmann, 2010); interaction in a multidisciplinary team as knowledge boundary spanning (Ratcheva, 2009); and cultural and linguistic boundary spanning in a multinational corporation (Barner-Rasmussen, 2017).

Central to boundary spanning are boundary spanners-people who can work across boundaries. Several characteristics are ascribed to these spanners: They seem to focus on interpersonal relationships, are entrepreneurial and innovative, act as cultural brokers, and exhibit trust and leadership. In order to cross boundaries, personal mobilities and interactions are assets for boundary spanners, since these facilitate the transfer of ideas, knowledge, and practices (Jöns \& Freytag, 2015).

In this article we argue that Somalis are boundary spanners par excellence because they use their transnational networks to cross different boundaries for several purposes, including socio-economic participation. Recognizing the capital that is developed through these acts of boundary spanning, also in informal ways, would do more justice to the lived experiences of Somali refugees, and providing greater flexibility to enable these boundary-spanning activities would help to strengthen the socio-economic position of Somali refugees. Although policymakers mainly understand socio-economic participation as a phenomenon that exclusively takes place within national borders, Somalis also participate in other spaces/sites. By showing how socio-economic participation works from a transnational perspective, we add another layer to the representation of Somalis in the Netherlands as a socio-economically weak and passive refugee group and show that a lot of their activities take place in another realm.

In the following section we describe the methodological foundations of this article and provide the background to the presence of Somalis in the Netherlands, with a special focus on their socio-economic participation in the Netherlands. We then discuss the role of their transnational network within this participation. We end with a discussion on the wider meaning of these findings concerning the role of transnational networks in socioeconomic participation.

\section{Methodology}

This contribution draws upon qualitative data collected in two research projects. The first study focused on the integration position of Somalis in Amsterdam and formed part of a larger European study on Somalis in European cities (Open Society Foundations, 2014). The second project investigated Somali diaspora organizations in the Netherlands and their transnational activities. Data for the first study were collected in 2013-14 through ten focus group discussions (FGDs) with Somalis in Amsterdam and interviews with stakeholders in Amsterdam and elsewhere. Some FGDs had a broad design, discussing multi- 
ple topics, while others had a more thematic focus, addressing education, employment, health, policing and security, and so on. The intention was to engage participants from a wide variety of backgrounds, and in particular a balance between women and men, different age groups, and different levels of education. Some of these criteria appeared difficult to meet, such as an equal representation of both genders in one FGD. Both men and women talked more openly when they participated in a group with people of the same sex. As such, this article provides more room to FGDs that involved only men or women. Another condition was that participants should not know each other. Since the Somali population in Amsterdam is very small this was difficult to accomplish. By using multiple entry points to this community, the Somalis who participated in the FGDs represented the broad diversity within the Somali community in Amsterdam. Most group discussions were conducted in Somali except for those with young Somalis and a group of older Somalis who have lived in Amsterdam since the early 1990s. All FGDs were recorded and transcribed by two Somali research assistants (Open Society Foundations, 2014).

Tables 1 and 2 provide an overview of some of the basic characteristics of the participants in the FGDs. About $40 \%$ were women, and a majority of all participants had arrived in the Netherlands after 2005. A majority of the participants were relatively young (i.e., in their twenties or thirties), which is a fair reflection of the presumed age distribution of the Somali population in Amsterdam.

In addition, 23 interviews were conducted with key individuals, such as city officials working in relevant departments, leaders of Somali organizations, representatives of non-governmental organizations working in relevant fields, journalists, and policy officers working in the national government.

For the second study, which was conducted in 2010-13, we started by mapping Somali organizations in the Netherlands. We then selected the 20 most important organizations and interviewed their boards. The topics addressed included the aims of the organization, the characteristics of their activities in the Netherlands, in Somalia and elsewhere, and their views on development in Somalia.

\section{The Somali Diaspora}

Somalis who left their country as asylum seekers are spread over the globe. Many have family members and relatives all over the world. The largest Somali diaspora is in America. Minneapolis-which is sometimes called 'little Mogadishu' - hosts the largest group of Somalis outside Somalia (Horst, 2007). The second largest Somali diaspora is in the UK. There is a strong tie between the two countries as a result of the colonial past and their common language. Migration has been taking place between Somalia and the UK since the 19th century. This migration started with seamen and steel workers who stayed on in the UK after doing temporary work during the colonial period (Griffiths, 2002; Kleist, 2004). As a result of this history, many Somalis in the UK live in harbour cities such as London, Liverpool, Bristol, or Cardiff, and in industrial cities such as Birmingham. Later, Somalis fleeing the civil war in Somalia in 1991 sought asylum in the UK. Yet later, a wave of European Somalis migrated from the Netherlands and Scandinavian countries (Bang Nielsen, 2004; Fangen, 2006) to the UK as EU citizens. These Somalis sometimes arrived in cities like Leicester that had large Muslim communities but no specific relation to Somali migration (van Liempt, 2011).

Although the Somali diaspora is geographically spread, they are psychologically and emotionally very much oriented towards Somalia. Research in the Netherlands showed that $84 \%$ of the Somalis in the Netherlands feel strongly attached to Somalia (Andriessen et al., 2017). A large number of remittances are sent to Somalia and there are numerous projects in the Netherlands aimed at the development of Somalia. The high frequency of visits to Somalia by Somalis from the diaspora and the number of people who follow the daily news in Somalia also evidence this strong orientation towards the homeland. Many Somalis send money home, as explained by one of the leaders of a Somali development organization:

There is a huge difference between transnational development activities and remittances: Remittances are not development activities; they are compulsory, a moral obligation. People always feel the pressure. You get phone calls every day, SMS: 'When will you

Table 1. Study 1: Participants in FGDs according to gender and year of arrival in the Netherlands.

\begin{tabular}{lccccc}
\hline & Before 1995 & 1995-99 & 2000-04 & After 2005 & Born in the Netherlands \\
\hline Male $(\mathrm{N}=39)$ & 9 & 3 & 1 & 21 & 5 \\
Female $(\mathrm{N}=27)$ & 2 & 3 & 3 & 18 & 1 \\
\hline
\end{tabular}

Table 2. Study 2: Age of participants in FGDs.

\begin{tabular}{lcccccc}
\hline Under 20 & $20 \mathrm{~s}$ & $30 \mathrm{~s}$ & $40 \mathrm{~s}$ & $50 \mathrm{~s}$ & $60 \mathrm{~s}$ & Unknown \\
\hline 4 & 26 & 16 & 11 & 5 & 1 & 3 \\
\hline
\end{tabular}


send money?' The vast majority of Somalis in the Netherlands are not involved in development activities, in structural activities. No, they just remit.

Of the roughly 40,000 Somalis in the Netherlands (on 1 January 2019 there were 39.947 Somalis registered; see CBS, 2019) one third were born in the Netherlands. Most Somalis live in Amsterdam, Rotterdam, Tilburg, or the Hague, although many of them first lived in other parts of the country as a result of the Dutch dispersal policy. Research shows that only one third of Somalis still live at the addresses they were originally dispersed to. The rest have moved on (van den Tillaart, 2000) to access job opportunities and/or be closer to friends and family. This is also in line with the study by Zorlu and Mulder (2008), who pointed out that over time some of the dispersed refugees regroup in larger cities.

The Somali community in the Netherlands is usually categorized into two groups, namely Somalis who arrived at the start of the 1990s, right after the collapse of the regime of Siad Barre, and those who came from 2007 onwards. The contrast between the two groups is big. The first group is mainly from the north and from urban areas and is relatively well educated (diplomats and businessmen, many with a university background). The second group is younger and mainly consists of people from the south, the majority from Mogadishu (Moors, van den Reek-Vermeulen, \& Siesling, 2009). This group is less well educated and until they came to the Netherlands, most of them had lived all their lives in a country at war. These Somalis have not had the same opportunities as the first group to, for example, attend school. Since 2007, there has been a low but steady inflow of Somalis into the Netherlands.

\section{Socio-Economic Participation of Somalis in the Netherlands}

The economic participation of refugees is not straightforward and in general does not evolve smoothly (see e.g., de Vroome \& van Tubergen, 2010). In 2013, only $46 \%$ of all refugees had a job and, in many instances, this was a part-time job without a fixed contract (VluchtelingenWerk, 2014). The situation of Somalis is worrisome. For example, in 2016, only $34 \%$ of Somali men were employed; for Somali women, the figure was $13 \%$. In addition, $54 \%$ of Somali men depended on welfare in 2016; for Somali women, the figure was $71 \%$ (CBS, 2018).

Figure 1 shows that unemployment is the highest compared to any other refugee or immigrant group in the Netherlands. In 2016, 34\% of Somalis were unemployed-twice as many as other non-Western immigrants.

In addition to showing how Somalis' unemployment figures differ from those of non-Western immigrants and autochthonous people, Figure 1 also shows that Somalis' unemployment has been hit hard by the economic reces- sion that started in 2008, which can be explained by the vulnerable and often temporary jobs Somalis have in the Netherlands. Only a third of Somalis who work have permanent jobs; the rest work part time and often without fixed contracts (Andriessen et al., 2017). They also earn very little and with the possibility of receiving benefits there is not much incentive to stay in precarious and low paid jobs. During one of the FGDs, a 45-year-old man pointed out how he thought the welfare system in the Netherlands was unfair:

I do not think the system is fair. I work 40 hours per week, get up at 5.30 every day, spend eight hours in a noisy factory, and return home tired. For all this, I receive $€ 1,200$ every month. My Somali friend here gets up at 10 , watches television all day, and receives only $€ 100$ less.

Apart from precarious jobs, low pay, and the possibility of receiving benefits in the Netherlands, the literature also points out that the relatively high levels of unemployment among Somalis can be explained by the 'refugee gap' (Connor, 2010). The educational and job careers of most Somali refugees have been interrupted by war and their escape from it. This is aggravated by specific context-related issues. Dutch asylum and integration policies do not allow asylum seekers to work when they first arrive, and then later on force them to integrate quickly. The asylum process and the long waiting times have often made this gap bigger (Engbersen et al., 2015). Difficulties getting diplomas certified or recognized can result in the gap never being completely closed. Moreover, Somalis face double discrimination on the labour market because they are both black and Muslim.

The language barrier and a lack of knowledge about how the labour market works in Europe also makes it hard for Somalis to find their way on the Dutch labour market. Especially, the recent arrivals with lower educational levels are struggling to learn Dutch (de Waal, 2017; Open Society Foundations, 2014), which makes it more difficult to participate socially and economically. Many Somalis feel caught in a vicious circle: Because they do not speak Dutch well, it is hard to find a job, and because they do not work, it is hard to improve their Dutch.

The way refugees can use their social capital differs from the way other people can use theirs because refugees' networks often consist of people who also have little knowledge of the Dutch labour market and often lack connections that can improve socioeconomic integration. Van Tubergen (2011) found that jobless refugees in the Netherlands often seek work through employment agencies rather than through families or friends. This could be because refugees' co-ethnics are also not so well connected to the Dutch labour market and that refugees have few contacts outside their co-ethnic networks. Some of the Somalis in the Netherlands, especially the older and the lower educated ones, have networks that consist 


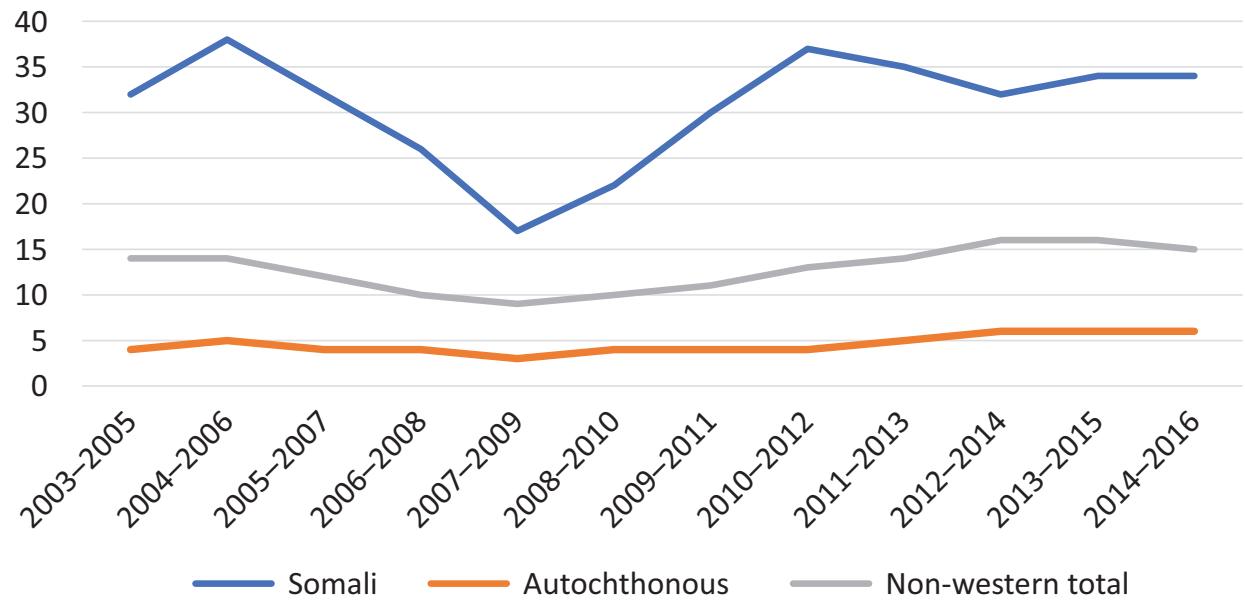

Figure 1. Unemployment figures for Somalis, autochthonous people and non-Western total, in the Netherlands 2003-2016, in percentages (based on Andriessen et al., 2017).

mainly of other Somalis. The same applies to women with young children, because they mostly interact with other Somali women (Open Society Foundations, 2014). Young Somalis have the most diverse social networks (Andriessen et al., 2017). There are also differences between the first and second group of arrivals; for example, the 'newcomers' seem to interact more exclusively with other Somalis compared to those who arrived in the 1990s. However, transnational networks play an important role in the lives of all Somalis in the Netherlands. Many, for example, have connections to Somalis in the UK, which sometimes makes it easier to find a job in the UK than in the Netherlands. The head of a Somali organization explained to us how in the mid-2000s, many Somali men moved to the UK to find work:

In 2005 we started IFTIN [Stichting Somalische vrouwen Amsterdam en Omstreken-Somali Women in Amsterdam and the Surroundings Foundation]. At that time, a lot of Somali families were leaving for the United Kingdom. Most of the time, the man - the provider of the family-went first. These men were highly educated and not satisfied with their situation; living on benefits was not why they had come to the Netherlands.

Size also matters. Refugees are a small and relatively new community, which means that people are dependent on small networks. The networks of refugees are thus often less equipped to support socio-economic participation at the local level in the new place of arrival. Their networks are also often relatively small as a result of migration and dispersal.

The unemployment figures show that there are quite substantial differences within the group of Somalis (as mentioned, in 2016, $34 \%$ of the men had a job, while only $13 \%$ of the women had one; CBS, 2018). Somali women are less oriented towards the Dutch labour market and more oriented towards their families than men, because most of them have caring obligations (Pels \& de Gruijter, 2005). Our interviews show that some women encounter barriers when it comes to childcare possibilities, which makes it less easy to work. Some Somali women want to work but do not know how to arrange it in a situation where they are the only one responsible and their local network is too weak. For example, a 28-year-old Somali woman we interviewed said:

I would like to work, but I am a single mother. Who will take care of my kids? That is the problem. For a Dutch mother, it is not so hard to work, even when she has three kids. She has a safety net of grandmothers, neighbours and friends who can take care of her kids. Somali women do not have these safety nets when they arrive in the Netherlands.

Here we see that transnational networks can be useful for advice and support, but they cannot be used for practical matters such as daily childcare support, which can be an obstacle to finding a job and thus to the socioeconomic participation of Somali women.

Discrimination on the Dutch labour market also needs to be looked into when trying to explain the high levels of unemployment amongst Somalis. The Somalis we interviewed told us that sometimes the employment agency explicitly stated that certain jobs were not meant for them-even in the case of lower skilled jobs. One 32year-old Somali man explained how he had been discouraged from applying for a job as a rubbish collector:

I wanted to apply for a job as a rubbish collector. But they told me that this was a job for which you need Dutch citizenship. I told them no problem, I'm Dutch. Well, he said, I am sorry but you cannot get this job.

Many interviewees said that the reasons they had been given for not getting a certain job, or not even being allowed to apply for it, were unclear and unjust. 
Finally, it is known that mental health problems and daily stress, and worrying about relatives who are still in a war zone or are trying to escape from one, can make it difficult for refugees to participate in society in general (Bakker, 2016; Dourleijn \& Dagevos, 2011; Engbersen et al., 2015; Maliepaard, Witkamp, \& Jennissen, 2017). As a result of the high unemployment rate in the Netherlands and the difficulties that Somalis encounter when trying to find jobs, a large number of Somalis live on benefits (Andriessen et al., 2017): In 2015, for example, $52 \%$ of Somalis aged between 15 and 65 years received social security benefits. The majority of those receiving benefits were women or people aged 45 or over-a worrisome situation. On the other hand, we see an increase in the number of people doing 'voluntary' jobs (Andriessen et al., 2017), which might be an indication that they find alternative ways to participate in the labour market.

Studies on Somalis point out that they have very strong transnational orientations. From research we know that these networks are important for social, cultural, and political reasons (Bang Nielsen, 2004; Hammond, 2015; Horst, 2006), but we do not know much about what these networks actually do or mean in the context of economic participation, or whether they impede or support the participation of Somalis in host societies. In the following section, we explore two forms of socio-economic participation of Somalis in the Netherlands that are facilitated by Somali transnational networks, namely working for Somali organizations in the Netherlands that are focused on developing Somalia, and moving to the UK from the Netherlands to work as an entrepreneur. We opted for these two forms of socioeconomic participation as they clearly reflect the use of transnational networks.

\section{Making a Job out of Participation in Somali Organizations}

One way of participating socio-economically in the Netherlands by using Somalis' transnational networks is to make a job out of social, cultural, and political activities organized by Somali organizations in the Netherlands. There are around 160 active Somali organizations in the Netherlands (van Heelsum, 2011), mostly in the Randstad area. The organizational density amongst Somalis is very high as a result of the Dutch dispersal policy and also because of the clan structure (van Heelsum, 2011) and the high levels of mistrust among Somalis and the resulting lack of collaboration between the different groups. Another explanation for the high number of diverse organizations is the heterogeneity in their agendas: They all have different missions and very different scopes of orientation (Open Society Foundations, 2014). Somali organizations in the Netherlands can generally be divided into two groups. One group offers local support to help Somalis integrate themselves into the Netherlands. Examples of such orga- nizations are Dalmar, SOMVAO, and the umbrella organization FSAN. They offer practical support to the Somali community like conversation classes, support for students with finding internships, and various sorts of information events. The other group is made up of organizations mainly orientated towards Somalia. They work around topics such as female genital mutilation, healthcare, peacebuilding, and social and economic development in Somalia. Examples of such organizations are HIRDA and NedSom.

Both types of organizations provide important 'participation spaces' for Somalis in the Netherlands, as they offer both voluntary and paid jobs. Of the 20 organizations we interviewed, five had paid staff. It should be noted that paid staff often have temporary part-time jobs that are strongly dependent on outside funding, which may come from the local or national government in the context of civic integration, for example an organization subcontracted by a municipality to provide training, or for projects in the field of international development, through the Ministry of Foreign Affairs or development NGOs. In the period 2004-2010, the Dutch government actively promoted diaspora engagement in development cooperation through migration and development policies. The underlying rationale was that migrants with knowledge of the area and linguistic capacities would have added value as experts in development cooperation programmes. These co-development programmes consisted of matching funds, capacity building, and temporary deployment schemes (Frouws \& Grimmius, 2012; Nijenhuis \& Broekhuis, 2010). Somali organizations were eligible for funding, and at least four of the organizations we interviewed had managed to access some of these co-development funds. The importance of such funds is in line with the findings of Moret (2018, p. 163), who points out how one of her interviewees participated in the Netherlands in the founding of an NGO with a strong transnational orientation towards Somaliland and the objective of rebuilding social infrastructure there, with financial support from the Ministry. Upon her relocation to the UK, she founded a UK branch of this organization. Interestingly, one of her respondents mentioned that she regularly returns to the Netherlands, as it is easier to get funding there. This illustrates the importance of transnational networks and the boundary-spanning capacities of Somalis engaged in these organizations. Notwithstanding the presence of funding opportunities, these jobs are also vulnerable as they are mostly temporary and highly dependent on subsidiary frameworks, which are becoming more transnational and competitive. Some of our interviewees said that it is becoming more difficult for Somali organizations in the Netherlands to get funding, because there is less national funding available and at the European level one now needs to compete with European partners with very impressive track records.

Three quarters of the organizations interviewed received support from between three and over 300 volun- 
teers. These volunteers are indispensable for the organizations, in terms of labour and network, as the following quote illustrates:

Many of our projects could not be carried out without the help of our volunteers. We have a pool of some 30, 35 people who provide support in a more structural way-in fundraising, the practical organization of events, or giving presentations at secondary schools. They have their own expertise. One of our volunteers was trained as a controller in an educational institution, so he helps us with financial issues. (Chair of a Somali organization, Amsterdam)

Although Somali organizations in the Netherlands that focus on Somalia have philanthropical motives, some volunteers expect and hope that their activities will result in economic gain. They regard this type of volunteering often as an investment in their future as well and some talk about these transnational activities in terms of 'exploring a possible return,' framed by Sagmo (2015) as a 'return assessment.' As one respondent, who runs a small charity, remarked:

We do small projects in Somalia, and it is mostly our local partners who do the actual implementation. But I go twice a year as well, to talk with people at the Ministry and with NGOs. Actually, it is not only to explore opportunities now, but also to explore options for the future, as I might go back to Somalia. (Male respondent, 2011)

This finding is in line with the observations of Sagmo (2015, p. 657) in her study on return visits by Burundian migrants living in the UK and Norway. She argues that regular visits are deemed important when migrants are planning a more permanent return. In order to make such a return, they need to secure economic capital and return visits are used to explore 'niches' in the market that might be used to set up a business. Other authors also refer to economic motives, in terms of employment and job creation, to establish or become engaged in a migrant organization (Griffiths, 2000; Open Society Foundations, 2014). Idil Osman (2017) also describes how the Somali diaspora elite saw opportunities and possibilities for themselves in Somalia during election time, and travelled back and forth constantly between the UK and Somalia to network and lobby-a phenomenon also observed by Hammond (2015). During our fieldwork we too observed this, with people going to and from to Somalia on a regular basis. Such 'pendular mobility' is also mentioned by Moret (2018, p. 167), who describes how interviewees who run a Somali organization can be characterized by transnational living. They frequently travel to Somalia, building social and cultural capital in such a way that they might be able to get a job in this field. In short, they intend to validate their capitals, making use of their transnational assets, namely their exposure to the 'West' and their networks and linguistic and cultural skills related to their Somali background (Hansen, 2014; Kleist, 2007). Having citizenship in the Netherlands enables a mobile livelihood strategy, and the large majority of the migrant organizations we interviewed considered citizenship a prerequisite to running the organization.

Somali organizations in the Netherlands that focus on Somalia use their networks in different ways. Strong ties, like family, where trust plays an important role, are used to ensure that local projects are run properly. For example, they function as a local entry point where containers of goods can arrive, local people can be paid and problems can be solved:

In Somaliland we work with a guy we've known for a very long time. A few years ago, he returned, and since then we contract him for projects, to hire construction workers for example and to oversee the work. So, in a way, we also create jobs. (Board member of a Somali organization, the Hague)

The weaker ties-such as contacts with other development organizations, ministries and coalition partnersare important for sharing information about, for example, funding opportunities. Somalis thus use their human capital, in the form of knowledge and contacts, to improve their own economic situations.

Boundary spanning is essential in this case for making the activities of these organizations a success. Those who run these organizations often have traits that are commonly ascribed to boundary spanners. They speak Dutch with ease, have knowledge of Dutch and European funding opportunities, and know how to access networks at different levels to raise money. They also have strong and weak connections in Somalia that make all of this possible.

\section{Becoming a Self-Employed Entrepreneur in the UK}

Around the year 2000, many Somalis started to leave the Netherlands to try their luck in the UK (van den Reek \& Hussein, 2003; van Liempt, 2011). Research has shown that there are many explanatory factors behind this, such as reuniting with the larger Somali diaspora for social and cultural reasons. But economic considerations also played an important role: Many Somalis were unsatisfied with their economic position in Dutch society and frustrated that their skills were not recognized. The language barrier also played a role in some decisions to move to the UK, where there were better job prospects.

The UK was assumed to be a country where it is easier to start your own business. In the Netherlands, many Somalis want to start a business, but most do not succeed or even start because of regulations and other obstacles. In the Netherlands it is important to have certificates, which makes it harder to start a business if you are from another country. There are also regulations and 
formal requirements, such as permits, that are not easy to understand-especially if you are not fluent in Dutch. Dagevos and Odé showed that, in 2008, less than $1 \%$ of Somalis were registered as self-employed entrepreneurs (Dagevos \& Odé, 2011). This figure has recently increased a little, but at the turn of the century it was very low.

In the UK there is a longer history of family-run shops. Such shops are dependent on cheap and sometimes free labour provided by family members and friends (Theodorakopoulos \& Ram, 2007). Most Somali shops run by Dutch Somalis in the UK are family run. It was discussed in the FGDs how much easier it is to enter the system in the UK and that one does not always need certificates to set up a business. As such, there is more space for boundary spanning between formal and informal aspects of labour participation. The UK system is perceived as rewarding experience rather than focusing on the possession of certificates, which is what Somalis experience in the Dutch system (see also Momatrade Consultancy, 2004).

This shows that the transnational networks of Dutch Somalis extend beyond connections between the Netherlands and Somalia (Moret, 2016; Open Society Foundations, 2014) and involve other countries and specific cities and even specific connections to Somali entrepreneurs.

Many of the Somalis who left the Netherlands to settle in the UK perceived starting a business as an attractive alternative to formal employment. We argue that those who moved to the UK to start a business can be conceptualized as boundary spanners, because they found a way to overcome obstacles on the Dutch formal labour market by making use of their own networks in innovative ways and moving beyond the national market that they were supposed to integrate into. Many already knew somebody who ran a business in the UK. Through them they had heard that the rules and regulations around starting a business in the UK were less strict than in the Netherlands (Klaver, Poel, \& Stouten, 2010; Open Society Foundations, 2014; van den Reek \& Hussein, 2003). With this specific access to local knowledge and networks, they can be seen as cultural and institutional brokers. Dutch Somalis' alternative economic strategies that span national borders and involve transnational economic activities fit very well with Williams's (2002) description of boundary spanners as entrepreneurial and innovative. Their willingness to move is fundamental to their stretching of the labour market.

\section{Conclusion}

Somalis receive a lot of attention in the media and from policymakers in the Netherlands and elsewhere, often for negative reasons. Because they have a higher unemployment rate than any other refugee group, it is often argued that their prospects are poor. Our research shows that Somalis indeed face many difficulties accessing the Dutch formal labour market, because they lack human and social capital and suffer from mental health problems and discrimination. However, in this article we showed that Somalis also actively use their transnational networks to participate socio-economically. The labour markets in which they participate are, however, not always fixed to national territories and they do not always start in the formal paid sector. We found that outside formal channels, Somalis sometimes manage to find job opportunities, either through voluntary or self-created jobs, for example in the context of Somali organizations in the Netherlands or on the margins of the British labour market, where it is easier to bend the rules and regulations and start a small business and become self-employed.

A broader type of participation needs to be included in the definition of 'participation' to understand the real participation of Somalis. Dagevos (1998) has called these jobs 'ethnic functions' - often jobs that are not paid but are very important in initiating participation in a new labour market. Funding structures for self-organizations used to be supportive of these types of jobs, but they are currently under pressure because of budget cuts. What is important to point out, however, is that these boundary-spanning activities between paid and voluntary jobs also move beyond national borders. In the case of Dutch Somalis, the UK is an important labour market and Somalis use their connections in the UK to increase their opportunities to participate economically there, mostly by starting a business, but also in Somalia there are opportunities for Somalis from the Netherlands to create jobs. Through our interviews we found that some Somalis in the Netherlands are actively orienting themselves towards Somalia, trying to create jobs and/or seeking future opportunities for jobs there.

Participation is generally only recognized when it takes place within national borders and in formal labour markets. To do justice to the transnational lives of Somalis-as illustrated by those who are involved in Somali organizations that span different contexts-and also to acknowledge the contribution to socio-economic participation that may potentially move across borders, it would make a difference if such manifestations of participation were valued for refugees in the future. Recognizing and accepting that transnationalism is a feature through which Somali refugees' daily lives and commitments-and thus also their socio-economic participation-takes place is important, as it also plays a crucial role in the way they belong to society. When livelihoods are transnational, commitments are more fluid and various boundaries need to be spanned.

Both forms of socio-economic participation we explored in this article show the important role of boundary spanners and their specific features: These are people who are able to cross boundaries through their personal mobilities and assets. These assets could be framed as capital, resources that can be used to improve their economic position (Moret, 2016). In the words of Williams (2007), Somalis access 'external knowledge, interpret it and refine it, adapting it to their specific context.' It 
should be noted that the role of the Dutch passport in this case is crucial, as it plays an essential role in giving Somalis access to both the Somali and the EU labour market, and in expanding their opportunities. Being more open to less formal and unpaid types of economic activities will be important in gaining recognition of the participation of Somali boundary spanners.

\section{Acknowledgments}

Part of this research was funded by Open Society Foundations under the Somalis in European Cities project (https://www.opensocietyfoundations.org/pub lications/somalis-european-cities-overview). A first draft of this article was presented at the IMISCOE conference on the 2nd of July 2018 in Barcelona in a panel organized by Marta Bivand Erdal, Jørgen Carling, Godfried Engbersen, Erik Snel and Özge Bilgili called 'New Empirical Research on Interaction between Integration and Transnationalism.' We want to thank the organisers and participants of this workshop for their critical comments.

\section{Conflict of Interests}

The author declares no conflict of interests.

\section{References}

Andriessen, I., Gijsberts, M., Huijnk, W., \& Nicolaas, H. (2017). Gevlucht met weinig bagage: De leefsituatie van Somalische Nederlanders [Fled with little luggage: The living conditions of Dutch Somalis]. The Hague: Sociaal en Cultureel Planbureau.

Bakker, L. (2016). Seeking sanctuary in the Netherlands: Opportunities and obstacles to refugee integration. Rotterdam: Erasmus Universiteit Rotterdam.

Bang Nielsen, K. (2004). Next stop Britain: The influences of transnational networks on the secondary movements of Danish Somalis (Working Paper No. 22). Sussex: Sussex Centre for Migration Research, University of Sussex.

Barner-Rasmussen, W. (2017). Linguistic skills: The fundament of boundary spanning in international organizational contexts? Bulletin VALS-ASLA, 106, 7-24.

CBS. (2018). Sociaaleconomische positie [Socioeconomic position]. CBS. Retrieved from https://www. cbs.nl/nl-nl/achtergrond/2018/47/ sociaaleconomische-positie

CBS. (2019). Statline: Population, sex, age and migration background. CBS. Retrieved from https:// opendata.cbs.nl/statline/\#/CBS/nl/dataset/37325/ table?ts $=1579872474805$

Connor, P. (2010). Explaining the refugee gap: Economic outcomes of refugees versus other immigrants. Journal of Refugee Studies, 23(3), 377-397.

Dagevos, J. (1998). Begrensde mobiliteit: Over allochtone werkenden in Nederland [Limited mobility: On mi- grant workers in the Netherlands]. Assen: Van Gorcum.

Dagevos, J., \& Odé, A. (2011). Inburgering en taal [Integration and language]. In E. Dourleijn \& J. Dagevos (Eds.), Vluchtelingengroepen in Nederland: Over de integratie van Afghaanse, Iraakse, Iraanse en Somalische migranten [Refugee groups in the Netherlands: On the integration of Afghan, Iraqi, Iranian and Somali migrants] (pp. 58-80). The Hague: Sociaal en Cultureel Planbureau.

Danso, R. (2001). From 'there' to 'here': An investigation of the initial settlement experiences of Ethiopian and Somali refugees in Toronto. GeoJournal, 56(1), 3-14.

de Vroome, T., \& van Tubergen, F. (2010). The employment experience of refugees in the Netherlands. International Migration Review, 44(2), 376-403.

de Waal, T. (2017). Conditional belonging: A legalphilosophical inquiry into integration requirements for immigrants in Europe (Unpublished Doctoral dissertation). Paul Scholten Centre for Jurisprudence, Amsterdam, the Netherlands. Retrieved from https://dare.uva.nl/search?identifier=aa9a125e5ebe-425a-90de-4a9578e3cefb

Dekker, R., \& Engbersen, G. (2014). How social media transform migrant networks and facilitate migration. Global Networks, 14(4), 401-418.

Dourleijn, E., \& Dagevos, J. (2011). Vluchtelingengroepen in Nederland: Over de integratie van Afghaanse, Iraakse, Iraanse en Somalische migranten [Refugee groups in the Netherlands: On the integration of Afghan, Iraqi, Iranian and Somali migrants]. The Hague: Sociaal en Cultureel Planbureau.

Engbersen, G., Dagevos, J., Jennissen, R., Bakker, L., Leerkes, A., Klaver, J., . . . Odé, A. (2015). Geen tijd te verliezen: Van opvang naar integratie van asielmigranten [No time to lose: From reception to integration of asylum migrants]. The Hague: WRR.

Fangen, K. (2006). Humiliation experienced by Somali refugees in Norway. Journal of Refugee Studies, 19(1), 69-93.

Frouws, B., \& Grimmius, T. (2012). Migratie en Ontwikkeling: Beleidsevaluatie van het Nederlandse migratie en ontwikkelingsbeleid sinds 2008 [Migration and development: Policy evaluation of Dutch migration and development policy since 2008]. Zoetermeer: Panteia.

Granovetter, M. (1973). The strength of weak ties. The American Journal of Sociology, 78(6), 1360-1380.

Griffiths, D. J. (2000). Fragmentation and consolidation: The contrasting cases of Somali and Kurdish refugees in London. Journal of Refugee Studies, 13(3), 281-302.

Griffiths, D. (2002). Somali and Kurdish refugees in London: New identities in the diaspora. Aldershot: Ashgate.

Hammond, L. (2015). Diaspora returnees to Somaliland: Heroes of development or job-stealing scoundrels? In L. Akesson \& M. Eriksson Baaz (Eds.), Africa's return 
migrants: The new developers? (pp. 44-63). London: Zed Books.

Hansen, P. (2014). Diaspora returnees in Somaliland's displacement economy. In A. Hammar (Ed.), Displacement economies in Africa: Paradoxes of crisis and creativity (pp. 145-160). London: Zed Books.

Horst, C. (2006). Transnational nomads: How Somalis cope with refugee life in the Dadaab camps of Kenya. Oxford and New York, NY: Berghahn.

Horst, C. (2007). The Somali diaspora in Minneapolis: Expectations and realities. In A. M. Kusow \& S. R. Bjork (Eds.), From Mogadishu to Dixon: The Somali diaspora in a global context (pp. 275-295). Asmara: The Red Sea Press.

Horst, C. (2008). The transnational political engagements of refugees: Remittance sending practices amongst Somalis in Norway. Conflict, Security \& Development, 8(3), 317-339.

Ismail, A. (2011). Diaspora and post-war political leadership in Somalia. Nordic Journal of African Studies, 20(1), 28-47.

Jöns, H., \& Freytag, T. (2015). Boundary spanning in social and cultural geography. Social \& Cultural Geography, 17(1), 1-22.

Kalter, F., \& Kogan, I. (2014). Migrant networks and labor market integration of immigrants from the former Soviet Union in Germany. Social Forces, 92(4), 1435-1456. https://doi.org/10.1093/sf/sot155

Klaver, J., Poel, P., \& Stouten, J. (2010). Somaliërs in Nederland, een verkenning van hun maatschappelijke positie en aanknopingspunten voor beleid [Somalis in the Netherlands, an exploratory study into their societal position and starting points for policy]. Amsterdam: Regioplan.

Kleist, N. (2004). Nomads, sailors and refugees: A century of Somali migration (Working Paper No. 23). Sussex: Sussex Centre for Migration Research, University of Sussex.

Kleist, N. (2007). Somali-Scandinavian dreaming: When 'the diaspora' returns to the desert. In N. N. Sørensen (Ed.), Living across worlds: Diaspora, development and transnational engagement (pp. 107-128). Geneva: IOM.

Maliepaard, M., Witkamp, B., \& Jennissen, R. (2017). Een kwestie van tijd? De integratie van asielmigranten: Een cohortonderzoek (Cahier 2017-3) [A matter of time? The integration of asylum migrants: A cohort study]. The Hague: WODC.

Massey, D., Arango, J., Hugo, G., Kouaouci, A., Pellegrino, A., \& Edward Taylor, J. (1998). Worlds in motion: Understanding international migration at the end of the millennium. New York, NY: Oxford University Press.

McKay, S. (2009). Looking for work: Exploring the job search methods of recent refugees and migrants. In S. McKay (Ed.), Refugees, recent migrants and employment: Challenging barriers and exploring pathways (pp. 200-214). London: Routledge.

Momatrade Consultancy. (2004). European conference on integration and migration: The Somali community in focus. Rotterdam: Momatrade Consultancy.

Moors, H., van den Reek-Vermeulen, E., \& Siesling, M. (2009). Voedingsbodem voor radicalisering bij kleine etnische groepen in Nederland, een verkennend onderzoek in de Somalische, Pakistaanse, Koerdische en Molukse gemeenschappen [Breeding ground for radicalization among small ethnic groups in the Netherlands, an exploratory study among Somali, Pakistani, Kurdish and Moluccan communities]. Tilburg: IVA.

Moret, J. (2016). Cross-border mobility, transnationality and ethnicity as resources: A study on European Somalis' post-migration mobility practices. Journal of Ethnic and Migration Studies, 42(9), 1455-1472.

Moret, J. (2018). European Somalis' post migration movements: Mobility capital and the transnationalisation of resources. Geneva: Springer.

Nijenhuis, G., \& Broekhuis, E. J. A. (2010). Institutionalising transnational migrant's activities: The impact of co-development programmes. International Development Planning Review, 32(3/4), 245-265.

Open Society Foundations. (2014). Somalis in Amsterdam. New York, NY: Open Society Foundations.

Osman, I. (2017). Media, diaspora and the Somali conflict. Amsterdam: Springer.

Pels, T., \& de Gruijter, M. (2005). Vluchtelingengezinnen en integratie. Opvoeding en ondersteuning in Iraanse, Irakese, Somalische en Afghaanse gezinnen in Nederland [Refugee families and integration. Parenting and support in Iranian, Iraqi, Somali and Afghan families in the Netherlands]. Assen: Van Gorcum.

Poros, M. (2001). The role of migrant networks in linking local labour markets: The case of Asian Indian migration to New York and London. Global Networks, 1(3), 243-259.

Portes, A., Escobar, C., \& Arana, R. (2008). Bridging the gap: Transnational and ethnic organizations in the political incorporation of immigrants in the United States. Ethnic and Racial Studies, 31(6), 1056-1090.

Ratcheva, V. (2009). Integrating diverse knowledge through boundary spanning processes: The case of multidisciplinary project teams. International Journal of Project Management, 27(3), 205-215.

Ryan, L., Sales, R., Mary, M., \& Siara, B. (2008). Social networks, social support and social capital: The experiences of recent Polish migrants in London. Sociology, 42(4), 672-690.

Sagmo, T. V. (2015). Return visits as a marker of differentiation in the social field. Mobilities, 10(4), 649-665. https://doi.org/10.1080/17450101.2014.891860

Snel, E., Engbersen, G., \& Leerkes, A. (2006). Transnational involvement and social integration. Global Networks, 6(3), 285-308.

Theodorakopoulos, N., \& Ram, M. (2007). An examination of the Somali enterprises activity in Leicester: Profile, drivers and barriers. Leicester: Centre for Research in Ethnic Minority Entrepreneurship.

van den Reek, E., \& Hussein, A. I. (2003). Somaliërs 
op doorreis, verhuisgedrag van Nederlandse Somaliërs naar Engeland [Somalis in transit, relocation behaviour of Dutch Somalis to the UK]. Tilburg: Wetenschapswinkel.

van den Tillaart, H. (2000). Nieuwe etnische groepen in Nederland [New ethnic groups in the Netherlands]. Nijmegen: ITS.

van Heelsum, A. (2011). Somaliërs in Nederland, profiel 2011 [Somalis in the Netherlands, a profile 2011]. The Hague: Ministerie van Buitenlandse Zaken.

van Liempt, I. (2011). And then one day they all moved to Leicester. Population, Space and Place, 17(3), 254-266.

van Tubergen, F. (2011). Job search methods of refugees in the Netherlands: Determinants and consequences. Journal of Immigrant \& Refugee Studies, 9(2), 179-195. https://doi.org/10.1080/ 15562948.2011.567157

VluchtelingenWerk. (2014). Integratiebarometer. Een on- derzoek naar de integratie van vluchtelingen in Nederland [Integration barometer. A study into the integration of refugees in the Netherlands]. Amsterdam: Vluchtelingenwerk.

Waldinger, R., \& Fitzgerald, D. (2004). Transnationalism in question. American Journal of Sociology, 109(5), 1177-1195.

Weerts, D. J., \& Sandmann, L. R. (2010). Community engagement and boundary spanning roles at research universities. The Journal of Higher Education, 81(6), 702-727.

Williams, P. (2002). The competent boundary spanner. Public Administration, 80(1), 103-124.

Williams, A. (2007). Listen to me, learn with me: International migration and knowledge transfer. British Journal of Industrial Relations, 45(2), 361-382.

Zorlu, A., \& Mulder, C. (2008). Initial and subsequent location choices of immigrants. Regional Studies, 42(2), 245-264.

\section{About the Authors}

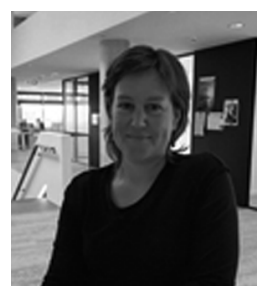

Ilse van Liempt $(\mathrm{PhD})$ is an Assistant Professor in the Department of Human Geography and Spatial Planning at Utrecht University. Her research interests and majority of publications are in the field of international migration, processes of inclusion and exclusion, qualitative research, identity, public space, and cities.

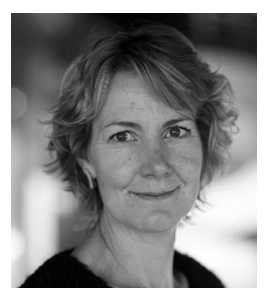

Gery Nijenhuis (PhD, Utrecht University) is a Human Geographer, working at the Department of Human Geography and Spatial Planning at Utrecht University. Her research focuses on international migration and development, diaspora organizations and the training of intercultural competences in geography education. 